\title{
PENGEMBANGAN LEMBAR KEGIATAN SISWA (LKS) BERBASIS METODE PENEMUAN TERBIMBING UNTUK MENINGKATKAN KEMAMPUAN PEMAHAMAN KONSEP MATEMATIK SISWA KELAS VII SMP ISLAM KEPENUHAN KABUPATEN ROKAN HULU
}

\author{
Annajmi $^{1)}$, Azmi Asra ${ }^{2)}$ \\ ${ }^{1)}$ Fakultas Keguruan dan Ilmu Pendidikan Universitas Pasir Pengaraian \\ ${ }^{2)}$ Fakultas Keguruan dan Ilmu Pendidikan Universitas Pasir Pengaraian \\ Email: annajminajmi86@gmail.com dan zulhamasra@gmail.com
}

\begin{abstract}
The purpose of this research was to produce a student activity sheet based guided discovery method to improve understanding of the mathematical concept of junior high school students, determine the effectiveness and increase the ability of understanding mathematical concepts that students use the worksheet-based method of guided discovery. The method used was the development of research development model 4-D, that was define, design, develop and disseminate. The research was conducted in SMP Islam Kepenuhan of Rokan Hulu Riau with research subjects grade VIIIA. Student activity sheet and research instruments validated to the experts, then conducted limited field trial, resulting in the final and disseminate is the use of student activity sheet that has been developed on a broader scale, to subject teachers school math test field try to use this device. The results of the implementation of the trials showed Student Activity Sheet effective to use, as shown by an increase in the ability of students' understanding of the concept, where students in classical completeness there are 30 students who reached the KKM $\geq 70$ ie $83.33 \%$ of the proceeds from the pretest posttest whereas only 23 those students who completed ie $63.88 \%$, further capabilities increase student understanding of the concept of before and after learning that the average pretest results and the ability of understanding the concept 69.84 average yield of 81.35 posttest understanding of the concept. Based on the analysis of data, it is advisable to use a math teacher to student activity sheet based methods guided discovery learning.
\end{abstract}

Keywords : Methods Guided Discovery, The Ability of Understanding The Concept, Student Activity Sheet

\section{PENDAHULUAN}

Pembelajaran matematika sekolah, sebagaimana yang dijelaskan dalam Peraturan Menteri Pendidikan Nasional No. 22 Tahun 2006, bertujuan agar siswa memiliki kemampuan memahami konsep matematika, menjelaskan keterkaitan antar konsep dan mengaplikasikan konsep atau algoritma secara luwes, akurat, efisien, dan tepat dalam pemecahan masalah. Kemampuan pemahaman konsep merupakan salah satu kecakapan atau kemahiran matematika yang sangat penting dalam mencapai tujuan pembelajaran matematika. Pemahaman konsep yang baik akan turut mempengaruhi daya matematika siswa, jika siswa dapat memahami konsep matematika dengan baik, maka siswa dapat menganalisa permasalahan dan mampu untuk menyelesaikan masalahnya. Sebagaimana yang dinyataan oleh Irawati (2014) bahwa kemampuan pemahaman konsep melandasi semua kemampuan daya ma- tematik. Hudiono (2010) juga menjelaskan bahwa pemahaman konsep matematik berkaitan erat dengan daya matematika yang lain yaitu pemecahan masalah, koneksi, penalaran dan representasi matematik.

Kemampuan matematika siswa saat ini sebagaimana kondisi di lapangan berdasarkan hasil survei TIMSS tahun 2011 (2012), apabila dilihat dari konten yang diujikan untuk dimensi kognitif, siswa Indonesia memperoleh skor ratarata 378 untuk domain pengetahuan, 384 untuk penerapan, dan 388 untuk penalaran. Sementara itu, jika dilihat dari dimensi konten matematik yang diujikan skor rata-rata untuk Bilangan 375, Aljabar 392, Geometri 377, dan Peluang 376. Berdasarkan hasil yang diperoleh tersebut menunjukkan masih rendahnya kemampuan matematika siswa SMP di Indonesia.

Berkaitan dengan rendahnya kemampuan matematika siswa, dalam hal ini berkenaan dengan pemahaman konsep siswa dan proses pem- 
belajaran matematika di sekolah. Pembelajaran matematika saat ini umumnya guru masih menjelaskan materi dan memberikan siswa beberapa contoh soal kemudian dilanjutkan dengan memberikan soal latihan. Soal-soal yang digunakan hanya soal-soal rutin yang selalu diberikan kepada siswa. Kegiatan siswa hanya mengerjakan soal berdasarkan rumus yang ada dan berdasarkan contoh yang diberikan oleh guru, siswa tidak dilibatkan dalam proses penemuan rumus, melainkan rumus langsung diberikan oleh guru hal ini mengakibatkan siswa tidak terlibat secara aktif dalam pembelajaran. Pembelajaran yang dilaksanakan demikian mengakibatkan siswa menjadi bosan dan hanya menghafal rumus-rumus, pada akhirnya mengakibatkan kemampuan pemahaman konsep siswa tidak tercipta dengan baik.

Pembelajaran matematika yang dilaksanakan guru tersebut, dalam pelaksanaannya, guru jarang membuat/merancang sendiri perangkat pembelajaran yang disesuaikan dengan suatu metode pembelajaran dan kondisi siswa. Perangkat pembelajaran yang digunakan guru selama ini adalah Silabus, RPP, dan buku pegangan, dan LKS. Guru menyiapkan RPP dengan model atau pendekatan-pendekatan pembelajaran yang inovatif (yang tertulis di RPP) namun belum diimplementasikan dengan baik dan benar, seringkali RPP yang disiapkan tidak sesuai dengan proses pembelajaran yang dilaksanakan. Proses pembelajaran tidak mengarah kepada permasalahan-permasalahan yang kontekstual. Selain itu, LKS yang digunakan adalah LKS siap pakai yang isinya mengarah pada kesimpulan materi dan tidak sinkron dengan buku pegangan yang digunakan dan metode pembelajaran di RPP. Evaluasi pada LKS masih berupa tes objektif, sehingga tidak melatih siswa dalam penyelesaian masalah. Hal ini berarti perangkat pembelajaran yang digunakan dalam proses pembelajaran tidak efektif terhadap pencapaian tujuan pembelajaran yang diinginkan.

Perangkat pembelajaran sangat penting dalam proses pembelajaran khususnya LKS, karena LKS membantu guru dalam mengantisipasi berbagai kemungkinan yang terjadi dalam proses pembelajaran, dimana proses pembelajaran merupakan proses yang kompleks sehingga berbagai kemungkinan bisa terjadi. Seorang tenaga pendidik yang profesional guru juga dituntut untuk memiliki kemampuan dalam mengembangkan perangkat pembelajaran, karena dengan mengembangkan perangkat pembelajaran guru dapat meningkatkan kreativitas dalam mengajar. Hal ini sesuai dengan yang dikemukakan oleh Mulyasa (2013), kreativitas dalam mengembangkan sumber belajar sangat penting, bukan karena keterbatasan fasilitas dan dana dari pemerintah, tetapi merupakan kewajiban yang harus melekat pada setiap guru untuk berkreasi, berinisiatif dan inovatif.

Menanggapi permasalahan tersebut, terutama berkaitan dengan rendahnya kemampuan pemahaman konsep matematis siswa yang akhirnya menyebabkan rendahnya hasil belajar siswa dalam pembelajaran matematika, maka guru perlu memilih pembelajaran yang dapat mengubah paradigma tersebut. Salah satu metode yang efektif dan memberikan pengaruh terhadap kemampuan pemahaman konsep matematis siswa adalah metode penemuan terbimbing. Andarwati dan Hermawati (2013) menyatakan bahwa metode penemuan terbimbing menempatkan guru sebagai fasilitator sehingga guru membimbing siswa hanya jika diperlukan saja. Metode ini mendorong siswa untuk berpikir sendiri, menganalisis sendiri sehingga dapat menemukan prinsip umum berdasarkan bahan atau data yang telah disediakan oleh guru. .

Metode pembelajaran penemuan terbimbing dapat membuat siswa aktif dalam proses pembelajaran. Perangkat pembelajaran khususnya LKS berbasis metode penemuan terbimbing penting dikembangkan untuk meningkatkan kemampuan pemahaman konsep matematis siswa. Hal ini didasari pada pengertian dan karakteristik metode penemuan terbimbing itu sendiri, menurut National Research Council (Sunismi dan Nu'man, 2012) metode penemuan terbimbing adalah rangkaian kegiatan pembelajaran yang menekankan pada proses berpikir secara kritis dan analitis untuk mencari dan menemukan sendiri jawaban dari suatu masalah yang dipertanyakan dengan bimbingan guru. Disamping itu, metode penemuan terbimbing merupakan salah satu cara untuk menyampaikan ide/gagasan dengan proses menemukan, dalam proses ini siswa berusaha menemukan konsep dan rumus dengan bimbingan guru.

Berdasarkan karakteristik dari metode penemuan terbimbing yang diharapkan dapat meningkatkan kemampuan pemahaman konsep matematik siswa, maka adapun tujuan dari penelitian ini adalah untuk menghasilkan produk yaitu Lembar Kegiatan Siswa (LKS) Berbasis Metode Penemuan Terbimbing yang valid dan efektif dan dapat meningkatkan kemampuan 
pemahaman konsep matematis siswa SMP Islam Kepenuhan.

\section{METODE PENELITIAN}

Jenis penelitian ini adalah penelitian pengembangan (development research). Pengembangan yang dilakukan adalah menghasilkan suatu produk yaitu Lembar Kegiatan Siswa (LKS) Berbasis Metode Penemuan Terbimbing.

Pengembangan lembar kegiatan siswa ini mengunakan Model pengembangan 4-D yang terdiri dari empat tahap yaitu tahap define (pendefinisian), design (perancangan), develop (pegembangan) dan disseminate (penyebaran). Secara rinci dapat dilihat pada Gambar 1.

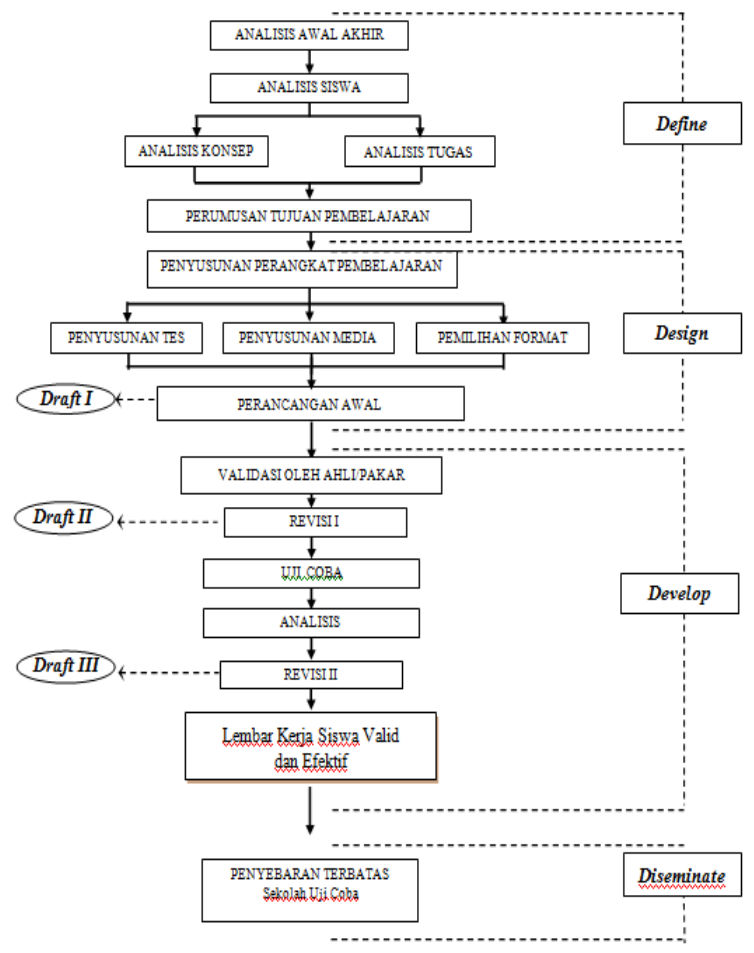

Gambar 1. Alur Pengembangan Lembar Kerja Siswa (Modifikasi dari Trianto, 2011)

Adapun tahap-tahap pengembangan lembar kegiatan siswa ini diuraikandengan sebagai berikut:

\section{Tahap Pendefinisian (define)}

Tujuan tahap pendefinisian adalah menetapkan dan mendefinisikan kebutuhankebutuhan pelajaran yang dilakukan dengan menganalisis tujuan dan batasan materi yang akan dikembangkan. Dalam tahap ini dilakukan analisis awal-akhir, analisis siswa, analisis tugas, analisis konsep dan perumusan tujuan pembelajaran.

JEP| Volume 1| Number 1| Mei 2017| Page 39-46

\section{Tahap Perancangan (design)}

Tujuan tahap perancangan (design) adalah merancang lembar kegiatan siswa (LKS), sehingga diperoleh prototipe (contoh LKS/Draf I). Tahap ini meliputi penyusunan tes, pemilihan media, pemilihan format dan perancangan awal.

\section{Tahap Pengembangan (develop)}

Tujuan tahap pengembangan adalah untuk menghasilkan LKS valid dan efektif. LKS draft 1 divalidasi kepada para ahli, selanjutnya dilakukan uji coba, yang bertujuan untuk memperoleh masukan langsung terhadap LKS yang telah disusun. Rancangan uji coba pada penelitian ini menggunakan rancangan One Group Pretest-Posttest Design. Langkah pertama melakukan pengukuran sebagai uji awal (pretest), selanjutnya dikenakan perlakuan dalam jangka waktu tertentu, kemudian dilakukan uji akhir (posttest).

\section{Tahap Penyebaran (diseminate)}

Tahap ini merupakan tahapan penggunaan LKS yang telah dikembangkan pada skala yang lebih luas. Penyebaran dalam penelitian ini dilakukan secara terbatas, yaitu dengan merekomemdasikan kepada seluruh guru mata pelajaran matematika sekolah uji coba yaitu SMP Islam Kepenuhan untuk menggunakan lembar kegiatan siswa ini sebagai salah satu alternatif pembelajaran pada materi bangun datar segiempat.

Instrumen penelitian yang digunakan adalah Lembar Validasi Lembar Kegiatan Siswa (LKS) dan Lembar Validasi Instrumen tes kemampuan pemahaman konsep matematik. Lembar Validasi ini digunakan untuk memperoleh data tentang kualitas lembar kegiatan siswa dan soal tes kemampuan pemahaman konsep matematis.

Data yang telah dikumpulkan selanjutnya dianalisis validitas dan efektifitas LKS yang telah dikembangkan. Adapun teknik analisis data yang digunakan dalam penelitian ini yaitu

\section{Analisis Validasi Lembar Kegiatan Siswa}

Validasi ini didasarkan pada pendapat ahli pada LKS yang telah dikembangkan. Hasil validasi ini selanjutnya diintrepesasikan berdasarkan Sinaga (2007) sebagai berikut:

$$
\begin{gathered}
1 \leq \mathrm{Va}<2 \\
2 \leq \mathrm{Va}<3 \\
3 \leq \mathrm{Va}<4 \\
4 \leq \mathrm{Va}<5 \\
\mathrm{Va}=5
\end{gathered}
$$

tidak valid kurang valid cukup valid valid sangat valid 


\section{Analisis Efektivitas}

a. Analisis Ketuntasan Belajar Siswa

Ketuntasan belajar siswa dianalisis dengan mempertimbangkan bahwa siswa dikatakan tuntas apabila nilai siswa secara individual mencapai skor $\geq 70$. Selanjutnya, pembelajaran dikatakan telah tuntas secara klasikal, yaitu terdapat $80 \%$ siswa yang mengikuti tes telah mencapai skor $\geq 70$.

b. Analisis Tujuan Pembelajaran

Tingkat ketercapaian tujuan pembelajaran dengan melihat setiap butir soal tes kemampuan pemahaman konsep menggunakan rumus Fauzi (Yuliani dan Saragih, 2015)

$$
\mathrm{T}=\frac{\text { Jumlah skor siswa untuk butir ke }-\mathrm{i}}{\text { Jumlah skor maksimum butir ke }-\mathrm{i}} \times 100 \%
$$

Kriterianya adalah:

$0 \% \leq \mathrm{T}<75 \% \quad$ : belum tercapai.

$75 \% \leq \mathrm{T} \leq 100 \% \quad$ : tercapai.

\section{HASIL DAN PEMBAHASAN}

Pengembangan dan produk dari penelitian pengembangan ini adalah Lembar Kegiatan Siswa Berbasis Metode Penemuan Terbimbing. Analisis data dan hasil penelitian yang diperoleh dalam setiap tahapan pengembangan disajikan sebagai berikut.

\section{Hasil Tahapan Pengembangan Lembar Kegiatan Siswa (LKS) \\ a. Tahap I Pendefinisian (Define)}

1) Analisis Awal Akhir

Berdasarkan hasil observasi terhadap lembar kegiatan siswa di SMP Islam Kepenuhan, menunjukkan bahwa masih ditemukan kelemahan pada lembar kegiatan siswa yang digunakan guru. Secara tidak langsung berkontribusi terhadap rendahnya kemampuan pemahaman konsep matematik siswa. Lembar kegiatan siswa yang dipakai oleh guru dan siswa, menghasilkan suatu pembelajaran yang berpusat pada guru sehingga siswa tidak aktif dalam pembelajaran. Selain itu, LKS digunakan sebagai penunjang kegiatan pembelajaran merupakan LKS siap pakai yang banyak diperjualbelikan yang isinya lebih mengarah pada kesimpulan materi bukan aktivitas atau kegiatan siswa. LKS yang digunakan juga cenderung isinya lebih mengarah pada soal-soal rutin bukan kegiatan siswa dalam menemukan konsep. Demikian pula dengan evaluasinya, masih berupa tes objektif., sehingga tidak melatih siswa dalam penyelesaian masalah. Hal inilah yang menjadi penyebab kemampuan pemahaman konsep matematis siswa masih rendah.

Selanjutnya, pemilihan materi bangun datar segiempat dalam pengembangan lembar kegiatan siswa ini didasarkan bahwa konsep bangun datar segiempat biasanya langsung diberikan sebagai sebuah konsep yang baku, sehingga siswa tidak dilatih untuk mengkonstruk pengetahuannnya dalam menemukan konsep bangun datar segiempat itu. Akibatnya pembelajaran yang diberikan menjadi kurang bermakna bagi siswa. Metode penemuan terbimbing diharapkan dapat menjawab masalah diatas untuk meningkatkan kemampuan pemahaman konsep matematis siswa. Oleh karena itu, perlu dikembangkan suatu lembar kegiatan siswa berbasis metode penemuan terbimbing yang baik.

2) Analisis Siswa

Analisis siswa dilakukan untuk menelaah karakteristik siswa yang sesuai dengan rancangan dan pengembangan materi pelajaran yang telah ditetapkan pada analisis awal akhir. Karakteristik ini meliputi pengembangan kognitif dan latar belakang pengetahuan siswa. Siswa SMP Islam Kepenuhan rata-rata berusia 14-15 tahun. Oleh karena itu, sangat tepat jika pembelajaran matematika diawali dengan benda konkret atau nyata yang dekat dengan kehidupan mereka, sehingga diharapkan dapat membantu meningkatkan kemampuan-kemampuan matematika siswa khususnya kemampuan pemahaman konsep matematis. Berdasarkan hasil wawancara dengan guru matematika kelas VII di SMP Islam Kepenuhan siswa sasaran di kelas VII adalah siswa yang heterogen, baik dilihat dari jenis kelamin maupun dilihat dari kemampuan kognitif siswa.

3) Analisis Konsep

Hasil analisis konsep yang diperoleh pada materi bangun datar segiempat mengacu pada Kurikulum KTSP yaitu sebagai berikut:
a) Materi Prasyarat
b) Pengertian Segiempat
c) Jenis-Jenis Segiempat
d) Sifat-Sifat Segiempat
e) Keliling Segiempat
f) Luas Daerah Segiempat

4) Analisis Tugas

Hasil analisis tugas yang diperoleh mengacu pada analisis konsep, disamping itu rincian analisis tugas untuk materi bangun datar segiempat merujuk pada standar kompetensi 
dan kompetensi dasar. Hasil analisis tugas dapat dilihat pada Tabel 1.

Tabel 1. Analisis Tugas Materi Bangun Datar Segiempat pada LKS

\section{Sub \\ Topik}

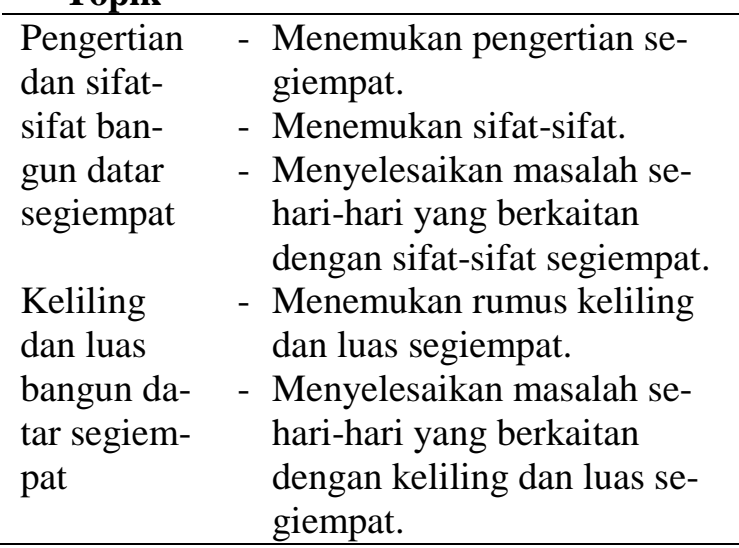

5) Perumusan Tujuan Pembelajaran

Hasil perumusan tujuan pembelajaran yang diperoleh disesuaikan dengan standar kompetensi dan kompetensi dasar kurikulum KTSP, seperti pada Tabel 2.

Tabel 2. Subtopik dan Tujuan Pembelajaran

\section{Sub Topik /Tujuan pembelajaran}

Sub Topik:

Pengertian dan sifat-sifat segiempat

Tujuan Pembelajaran:

a) Siswa menemukan pengertian segiempat.

b) Siswa mampu menemukan unsur-unsur segiempat.

c) Siswa mampu menyelesaikan masalah sehari-hari yang berkaitan dengan unsurunsur segiempat.

Sub Topik:

Keliling dan luas segiempat

Tujuan Pembelajaran:

a) Siswa mampu menemukan rumus keliling dan luas bangun datar segiempat.

b) Siswa mampu menyelesaikan masalah nyata yang berkaitan dengan keliling dan luas segiempat.

\section{b. Tahap II. Perancangan ( Design )}

Tujuan dari tahap ini adalah merancang lembar kegiatan siswa, sehingga diperoleh prototipe (contoh lembar kegiatan siswa) untuk materi bangun datar segiempat berbasis metode penemuan terbimbing.

1) Penyusunan Tes

Tes kemampuan pemahaman konsep matematis yang dirancang disesuaikan dengan jenjang kemampuan kognitif. Penskoran hasil tes menggunakan panduan evaluasi yang memuat kunci dan pedoman penskoran setiap butir soal. Adapun kisi-kisi tes pemahaman konsep matematis disusun berdasarkan indikator kemampuan pemahaman konsep yaitu : memberi contoh dan non contoh dari konsep, menyatakan ulang sebuah konsep, dan mengaplikasikan konsep ke dalam pemecahan masalah.

2) Pemilihan Media

Hasil pemilihan media disesuaikan dengan analisis konsep dan tugas. Media dan alat bantu pembelajaran materi segiempat yang digunakan diantaranya gambar-gambar benda yang permukaannya berbentuk segiempat dan yang dibuat dari kertas karton, gunting, penggaris, pensil dan benda-benda di sekitar sekolah yang berbentuk segiempat.

3) Pemilihan Format

Hasil pemilihan format LKS yang digunakan disesuaikan dengan format rencana pembelajaran dalam kurikulum KTSP. Sesuai dengan kurikulum KTSP, dalam LKS tercantum tujuan pembelajaran, kegiatan pembelajaran dan soal-soal latihan. Kegiatan pembelajaran sesuai dengan langkah-langkah metode penemuan terbimbing yang dibuat berwarna dan bergambar sehingga siswa akan tertarik dan termotivasi untuk belajar.

4) Perancangan Awal

Kegiatan dalam tahap ini yaitu perancangan/penyusunan lembar kegiatan siswa. Pada tahap ini dihasilkan rancangan awal LKS untuk setiap pertemuan dan tes kemampuan pemahaman konsep. Semua hasil pada tahap perancangan ini disebut Draf-I. LKS terdiri dari 4 set untuk 4 kali pertemuan. LKS yang dikembangkan sesuai dengan prinsip atau prosedur metode penemuan terbimbing. LKS yang dibuat memuat tentang nama kelompok, nama anggota kelompok, tujuan pembelajaran, materi bangun datar segiempat.
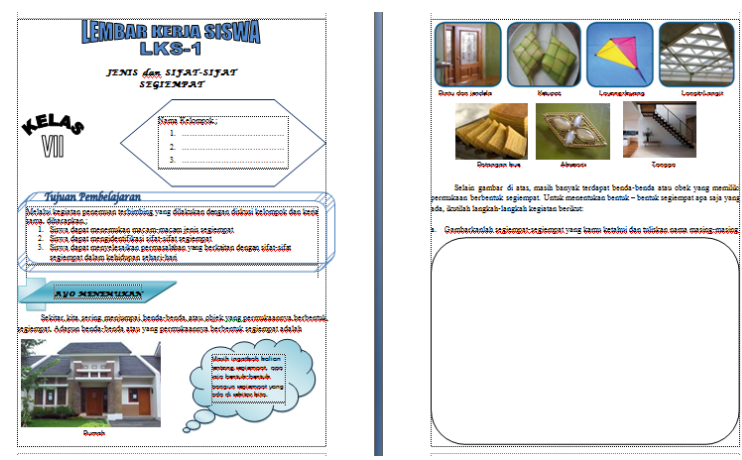

Gambar 2. Contoh Tampilan LKS 


\section{c. Tahap III. Pengembangan (Develop)}

Hasil dari tahap define dan design menghasilkan rancangan awal sebuah lembar kegiatan siswa yang disebut dengan draf I. LKS dalam bentuk draf I dilakukan uji validitas oleh pakar/ahli (expert review) dan uji coba.

1) Hasil Validasi Ahli

Penilaian yang dilakukan validator terhadap LKS meliputi: format, bahasa, ilustrasi, dan isi. Revisi dilakukan mengacu pada hasil diskusi dengan mengikuti saran-saran serta petunjuk validator. Validator menyimpulkan bahwa LKS dapat digunakan dengan revisi kecil.

Hasil validasi ahli terhadap LKS diperoleh rata-rata skor masing-masing aspek penilaian dari kelima validator adalah $\geq 4,0$ dengan kriteria "valid". Rata-rata skor seluruhnya terhadap penilaian LKS berada pada kriteria valid, yaitu sebesar 4,23.

2) Hasil Ketuntasan Belajar Siswa

Tingkat penguasaan siswa ditinjau dari hasil tes kemampuan pemahaman konsep matematis siswa disajikan pada Tabel 3.

Tabel 3. Hasil Tes Kemampuan Pemahaman Konsep Matematis

\begin{tabular}{cccccc}
\hline n & $\begin{array}{c}\text { Rata- } \\
\text { rata }\end{array}$ & $\begin{array}{c}\text { Nilai } \\
\text { Min }\end{array}$ & $\begin{array}{c}\text { Nilai } \\
\text { Mak }\end{array}$ & Tuntas & $\%$ \\
\hline 36 & 81,4 & 60 & 93 & 30 & 83,3 \\
\hline
\end{tabular}

Tabel 3 memperlihatkan bahwa $80 \%$ siswa dari hasil tes kemampuan pemahaman konsep yang mengikuti pembelajaran telah mampu mencapai skor $\geq 70$. Dengan demikian hasil postest kemampuan pemahaman konsep matematik telah memenuhi kriteria pencapaian ketuntasan klasikal.

3) Ketercapaian tujuan pembelajaran

Tingkat ketercapaian tujuan pembelajaran dari hasil posttest kemampuan pemahaman konsep dapat dilihat pada Tabel 4.

Tabel 4. Ketercapaian Tujuan Pembelajaran terhadap Kemampuan Pemahaman Konsep

\begin{tabular}{|c|c|c|c|}
\hline \multirow{2}{*}{ No } & \multirow{2}{*}{$\begin{array}{l}\text { Tujuan Pembe- } \\
\text { lajaran }\end{array}$} & \multicolumn{2}{|c|}{$\begin{array}{l}\text { Kemampuan Pe- } \\
\text { mahaman Konsep }\end{array}$} \\
\hline & & $\%$ & Ket \\
\hline 1 & $\begin{array}{l}\text { Siswa mampu } \\
\text { menyatakan ulang } \\
\text { konsep segiempat. }\end{array}$ & $85,42 \%$ & Tuntas \\
\hline 2 & $\begin{array}{l}\text { Siswa mampu } \\
\text { menentukan con- } \\
\text { toh dan bukan } \\
\text { contoh dari kon- }\end{array}$ & $88,54 \%$ & Tuntas \\
\hline
\end{tabular}

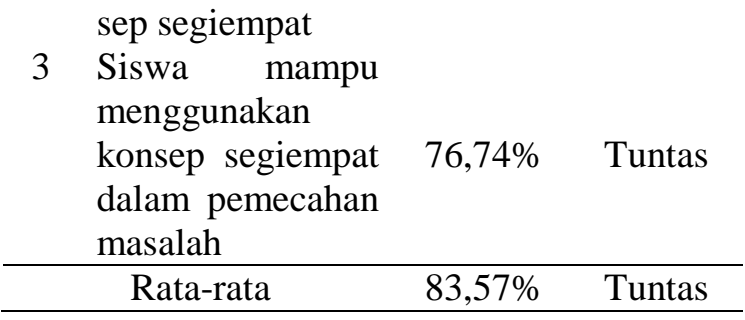

Berdasarkan Tabel 4 hasil tes kemampuan pemahaman konsep memperlihatkan bahwa ketercapaian tujuan pembelajaran sesuai dengan kriteria ketercapaian tujuan pembelajaran, yaitu $\geq 75 \%$ dari skor maksimum tiap tujuan pembelajaran, dengan demikian ketercapaian tujuan pembelajaran dari hasil posttest kemampuan pemahaman konsep sudah tercapai.

Lembar kegiatan siswa dalam bentuk draf II yang telah diuji cobakan di kelas VII SMP Islam Kepenuhan, secara keseluruhan, hasil analisis telah memenuhi kriteria efektif, seperti: hasil postest kemampuan pemahaman konsep matematis telah memenuhi kriteria pencapaian ketuntasan secara klasikal, ketercapaian tujuan pembelajaran telah mencapai kriteria yang ditentukan telah tercapai., pencapaian waktu pembelajaran yaitu minimal sama dengan pembelajaran biasa. Hasil analisis dan dengan sedikit revisi menghasilkan draf III atau lembar kegiatan siswa yang valid dan efektif.

\section{d. Tahap IV. Penyebaran (Diseminate)}

Pengembangan LKS mencapai tahap akhir dimana lembar kegiatan siswa telah memperoleh penilaian positif dari para ahli, yaitu valid dan efektif. Lembar Kegiatan Siswa Berbasis Metode Penemuan Terbimbing dalam penelitian ini penyebaran dilakukan secara terbatas hanya pada sekolah mitra saja yaitu SMP Islam Kepenuhan dari materi, kelas/siswa dan waktu (penyebaran khusus).

\section{Peningkatan Kemampuan Pemahaman Konsep}

Data hasil tes kemampuan pemahaman konsep siswa sebelum (pretest) dan sesudah (posttest) uji coba disajikan pada Tabel 5.

Tabel 5 . Hasil Tes Kemampuan

Pemahaman Konsep

\begin{tabular}{ccc}
\hline Keterangan & Pretest & Postest \\
\hline Nilai Mak & 79 & 93 \\
Nilai Min & 57 & 61 \\
Rata-rata & 69,84 & 81,35 \\
\%Tuntas & 63,89 & 83,33 \\
\hline
\end{tabular}


Berdasarkan Tabel 5, hasil analisis peningkatan kemampuan pemahaman konsep siswa menunjukkan bahwa rata-rata kemampuan pemahaman konsep siswa pada hasil pretest meningkat pada posttest. Hal ini terlihat adanya peningkatan nilai rata-rata kemampuan pemahaman konsep siswa sebesar 11,51.

\section{Pembahasan Hasil Penelitian}

Berdasarkan data yang diperoleh dari hasil pretest dan posttest dapat diketahui apakah rumusan masalah dan pertanyaan yang diajukan telah terjawab atau belum.

\section{a. Efektivitas Lembar Kegiatan Siswa}

Keefektifan LKS berbasis metode penemuan terbimbing dilihat dari tiga aspek yaitu ketuntasan belajar siswa, ketercapaian tujuan pembelajaran, dan waktu pembelajaran.

\section{1) Ketuntasan Belajar Siswa}

Berdasarkan hasil analisis data yang telah dikemukakan sebelumnya bahwa klasikal kemampuan pemahaman konsep adalah 83,33\%. Hasil tes ini menunjukkan bahwa ketuntasan belajar siswa secara klasikal dengan menggunakan lembar kegiatan siswa yang dikembangkan memenuhi kriteria keefektivan. Hal ini dikarenakan dengan menggunakan Lembar Kegiatan Siswa Berbasis Metode Penemuan Terbimbing siswa aktif mencari, menyusun sendiri pengetahuan, dan membuat kesimpulan dari pengetahuan yang ditemukan dengan bimbingan dan petunjuk dari guru berupa pertanyaan-pertanyaan yang mengarahkan. Hal tersebut diperkuat oleh Hamalik (2009) yakni metode penemuan terbimbing merupakan sistem dua arah yaitu melibatkan siswa dalam menjawab pertanyaa-pertanyaan yang diberikan oleh guru. Sehingga dapat disimpulkan bahwa lembar kegiatan siswa berbasis metode penemuan terbimbing mampu membantu siswa mencapai ketuntasan belajar secara klasikal.

\section{2) Ketercapaian tujuan pembelajaran}

Berdasarkan hasil analisis tingkat ketercapaian tujuan pembelajaran yang telah tercapai yaitu rata-rata $83,57 \%$. Hal ini menunjukkan bahwa Lembar Kegiatan Siswa Berbasis Metode Penemuan Terbimbing memenuhi kriteria keefektivan. Pembelajaran menggunakan Metode penemuan terbimbing sengaja dirancang agar siswa menemukan sendiri pengetahuannya dengan bimbingan guru berupa pertanyaan-pertanyaan, peragaanperagaan atau media lainnya yang diperlukan dalam mencapai tujuan pembelajaran.
Peran siswa sangat besar di dalam metode penemuan terbimbing sehingga guru tidak lagi berperan sebagai pihak utama yang terlibat di dalam proses pembelajaran. Seperti yang dikemukakan oleh Andarwati dan Hermawati (2013) metode penemuan terbimbing menempatkan guru sebagai fasilitator sehingga guru membimbing siswa hanya jika diperlukan saja.

\section{b. Peningkatan Kemampuan Pemahaman Konsep}

Berdasarkan hasil analisis hasil tes kemampuan pemahaman konsep siswa menunjukkan bahwa pembelajaran menggunakan LKS berbasis metode penemuan terbimbing dapat meningkatkan kemampuan pemahaman konsep siswa. Peningkatan kemampuan pemahaman konsep siswa ini dikarenakan siswa sendirilah yang menemukan konsepnya dan menguasai benar temuannya, sedangkan peran guru yaitu membimbing siswa dengan memberi arahan (guided) dan siswa didorong untuk berpikir sendiri sehingga dapat menemukan prinsip umum berdasarkan arahan/pertanyaan-pertanyaan yang diberikan oleh guru dan sampai seberapa jauh siswa dibimbing tergantung pada kemampuannya dan materi yang sedang dipelajari. Teori Piaget (Dahar, 2011) juga mengungkapkan bahwa siswa hendaknya dianjurkan untuk mempunyai pendapat sendiri, mengemukakannya, mempertahankannya, dan merasa tanggung jawab atasnya, walaupun sebagian dari gagasan mereka itu ada yang salah dan ada yang betul, dan gagasan-gagasan ini harus ditelusuri dan dikoordinasikan agar para siswa menjadi pemikir-pemikir yang diharapkan.

\section{KESIMPULAN}

Berdasarkan analisis pelaksanaan hasil uji coba menunjukkan Lembar Kegiatan Siswa (LKS) berbasis metode penemuan terbimbing efektif digunakan untuk meningkatkan kemampuan pemahaman konsep matematis siswa. Selain itu kemampuan pemahaman konsep matematik siswa meningkat dari sebelum dan sesudah pembelajaran yaitu rata-rata hasil pretest tes kemampuan pemahaman konsep 69,84 dan ratarata hasil posttest kemampuan pemahaman konsep 81,35 .

\section{DAFTAR PUSTAKA}

Andarwati, D., \& Hernawati, K. 2013. Pengembangan Lembar Kegiatan Siswa (LKS) 
Berbasis Pendekatan Penemuan Terbimbing Berbantuan Geogebra untuk Membelajarkan Topik Trigonometri pada Siswa Kelas X SMA. Yogyakarta: Prosiding Seminar Nasional Matematika dan Pendidikan Matematika, 09 November. (Online),

Dahar, R.W. 2011. Teori-teori Belajar. Jakarta : Erlangga.

Hamalik, O. 2009. Perencanaan Pengajaran Berdasarkan Pendekatan Sistem. Jakarta: Bumi Aksara.

Hudiono, B. 2010. Peran Pembelajaran Diskursus Multi Representasi terhadap Pengembangan Kemampuan Matematika dan Daya Representasi Siswa SLTP. Jurnal Cakrawala Kependidikan Volume 8 Nomor 2 .

Irawati, H. 2014. Pengaruh Pembelajaran Penemuan Terbimbing terhadap Kemampuan Pemahaman Matematik Siswa. Prosiding Seminar Nasional Pendidikan Matematika Program Pasca Sarjana STKIP Siliwangi Bandung. Volume 1 ISSN 2355-0473

Mulyasa, H. E. 2013. Pengembangan dan Implementasi Kurikulum 2013. Bandung: PT. Remaja Rosdakarya.
Peraturan Menteri Pendidikan Nasional No. 22 Tahun 2006 tentang standar isi mata pelajaran matematika

Sinaga, B. 2007. Pengembangan Model pembelajaran matematika Berdasarkan Masalah Berbasis Budaya Batak (PBMB3). Disertasi. Tidak diterbitkan. Surabaya: Program Pascasarjana UNESA Surabaya.

Sunismi. \& Nu'man, M. 2012. Pengembangan Bahan Pembelajaran Geometrid an Pengukuran Model Penemuan Terbimbing Berbantuan Komputer untuk Memperkuat Konsepsi Siswa. Cakrawala Pendidikan Volume 3, Nomor 2.

Trianto. 2011. Mendesain Model Pembelajaran Inovatif-Progresif. Jakarta: Kencana.

TIMSS. 2012. TIMSS 2011 International Result in Mathematics. Lynch School of Education, Boston College.

Yuliani, K dan Saragih, S. 2015. The Development of Learning Devices Based Guided Discovery Model to Improve Understanding Concept and Critical Thinking Mathematically Ability of Students at Islamic Junior High School of Medan. Journal of Education and Practice, Volume 6, Nomor 24. 